\title{
Reactivity between rheumatoid factor and rheumatoid tissue*
}

\author{
E.-J. MILDE
}

From the Broegelmann Research Laboratory for Microbiology, and the Department of Microbiology, The Gade Institute, School of Medicine, University of Bergen, Norway

Results obtained with the mixed agglutination procedure for demonstration of rheumatoid factor (RF) in synovial tissue from patients with rheumatoid arthritis (RA) have been presented in a previous paper (Milde and Tönder, 1968). Three test systems similar to those used to demonstrate RF in serum were used:

(1) Sheep erythrocytes sensitized by rabbit antiserum, (2) Human O-Rh-positive (CD) erythrocytes sensitized with anti-Rh serum,

(3) Rabbit erythrocytes sensitized with mercaptoethanol-treated pooled human serum.

In most cases sections of RA-tissue absorbed the sensitized erythrocytes. Results of inhibition experiments with denatured $\gamma$-globulin and antibodies to $\gamma \mathbf{M}$, indicated that the reaction depended on RF bound in the tissue.

In addition, tissue from some RA-patients absorbed RF. This activity was demonstrable using an indirect test in which RA-serum was applied to the tissue before the sensitized erythrocytes. Supposedly this activity depended on $\gamma$-globulin bound in the tissue in vivo. This paper presents further evidence for the existence of tissue-bound $\gamma$-globulin reactive with RF. Some properties of this reactant have been revealed. Some data on the quantitative ratios between RF and the reactant are given.

\section{Material and methods}

\section{PATIENTS}

Ten patients suffering from classical or definite RA were selected; ten patients with osteoarthritis in various joints and two with chronic infectious arthritis were selected as one control group; the second control group consisted of ten patients with no sign of arthritis.

\section{SERA}

These were obtained from patients and from blood donors. Incomplete anti-CD serum (Ripley) was kindly provided by Dr. Marion Waller, Department of Pathology, School of Medicine, Richmond, Va. Antisera to sheep erythrocytes were produced by immunization of rabbits. The sera were stored at $-20^{\circ} \mathrm{C}$. Before use they were heated at $56^{\circ} \mathrm{C}$. for $30 \mathrm{~min}$. (inactivated sera).

\section{ERYTHROCYTES}

Human and sheep erythrocytes were collected and handled as earlier described (Milde and Tönder, 1968).

\section{TISSUE}

Synovial tissue from various joints was collected during surgical operations. The tissue specimens were quickly frozen on dry ice. If not used immediately, they were stored at $-20^{\circ} \mathrm{C}$. Specimens of joint capsules, liver, spleen, skin, nerve, cancer, and chronically infected lung from the second control group were obtained at autopsy at the Department of Pathology, The Gade Institute, University of Bergen.

Tissue sections were prepared as previously described (Milde and Tönder, 1968). Frozen tissues were disintegrated using an X-press (AB Biox, Nacka 2, Sweden) (Edebo, 1960), and then lyophilized in a vacuum freezedryer. If not used immediately, the lyophilized tissues were stored at $-20^{\circ} \mathrm{C}$. In preliminary experiments, freshly disintegrated, not lyophilized, tissue preparations were used.

\section{TREATMENT OF TISSUE}

In some experiments tissue sections were exposed to $56^{\circ} \mathrm{C}$. by leaving the coverglasses for $30 \mathrm{~min}$. in beakers filled with phosphate buffered saline, $\mathrm{pH} 7 \cdot 2\left(150^{-1} \mathrm{M}\right.$ with respect to phosphate and $15^{-1} \mathrm{M}$ with respect to $\mathrm{NaCl}$ ) (buffered saline) or 15 per cent. $\mathrm{NaCl}$ and kept in a water-bath at $56^{\circ} \mathrm{C}$. Freshly disintegrated or lyophilized tissues were washed five times in large volumes of buffered saline and centrifuged at $14,500 \mathrm{G}$. for 20 min. between the washings. After the last washing the tissue sediment was packed at $17,000 \mathrm{G}$. for $30 \mathrm{~min}$.

In some experiments $200 \mathrm{mg}$. washed lyophilized tissue sediment was suspended in $5 \mathrm{ml}$. 15 per cent. $\mathrm{NaCl}$. The mixture was incubated at room temperature for 1 hour and centrifuged at $14,500 \mathrm{G}$. for $20 \mathrm{~min}$. The eluate was withdrawn and the tissue sediment submitted to one more elution. The tissue sediment was then washed five times in buffered saline and used in absorption experiments.

For heat elution of tissue sediment, the centrifugations 
had to be performed with another centrifuge. Washed tissue sediment was therefore packed at 1,500 G. for 1 hour. The same amount of washed tissue sediment as above was then suspended in $5 \mathrm{ml} .15$ per cent. $\mathrm{NaCl}$ and incubated at $56^{\circ} \mathrm{C}$. for 1 hour. The mixture was then centrifuged at $56^{\circ} \mathrm{C}$. at $1,500 \mathrm{G}$. for 1 hour. The sediment was washed five times in buffered saline at room temperature and used in absorption experiments.

In some experiments $500 \mathrm{mg}$. tissue were suspended in $5 \mathrm{ml} .0 .1 \mathrm{M}$ glycin- $\mathrm{HCl}$ buffer, $\mathrm{pH} \mathrm{3.4}$. The mixture was left at room temperature for 1 hour. After centrifugation at $14,500 \mathrm{G}$. for $30 \mathrm{~min}$., the eluate was withdrawn. This procedure was repeated once. Thereafter the tissue was suspended in $5 \mathrm{ml}$. of the acid buffer and the mixture left overnight at $4^{\circ} \mathrm{C}$. After centrifugation the supernatant was withdrawn. The sediment was then washed in buffered saline and used in absorption experiments.

\section{TESTS FOR RF IN SERUM}

The Waaler-Rose test and the test with human erythrocytes sensitized by anti-CD Ripley (anti-CD test) was performed as earlier described (Milde and Tönder, 1968).

\footnotetext{
ABSORPTION

In preliminary experiments freshly disintegrated washed tissues were used for absorption of serum by suspending $0.4 \mathrm{ml}$. packed tissue sediment in $3.5 \mathrm{ml}$. RA-serum diluted $1: 16$. The mixture was incubated at $4^{\circ} \mathrm{C}$. overnight. After centrifugation the serum was withdrawn. It was then mixed with another $0.4 \mathrm{ml}$. packed tissue and incubated at room temperature for 1 hour. In most experiments this last absorption was repeated once. Unabsorbed and absorbed serum was tested for RF. In other experiments lyophilized washed tissues were used for absorption of serum by suspending $100 \mathrm{mg}$. tissue in $4 \mathrm{ml}$. RA-serum diluted $1: 8$. The mixture was incubated at room temperature for 3 hours and then overnight at $4^{\circ} \mathrm{C}$. The serum was withdrawn after centrifugation (absorbed serum). In most experiments the absorption was repeated twice.
}

MIXED AGGLUTINATION WITH TISSUE SECTIONS The technique described earlier was followed (Milde and Tönder, 1968). The indicator system consisting of sensitized sheep erythrocytes was made as earlier described (Milde and Tönder, 1968), Sensitized human erythrocytes were prepared as follows: Human $\mathrm{OR}_{\mathbf{1}} \mathbf{R}_{\mathbf{2}}$ erythrocytes were washed three times and packed at 1,000 G. for $2 \mathrm{~min}$. One volume of packed erythrocytes was mixed with one volume of anti-CD serum Ripley at various dilutions. After incubation at $37^{\circ} \mathrm{C}$. for $90 \mathrm{~min}$. the sensitized erythrocytes were washed in large volumes of buffered saline and finally prepared as a 1 per cent. suspension. The activity in tissue was graded according to the strength of reaction between tissue sections and sensitized erythrocytes (strong, medium, weak, and none: Milde and Tönder, 1968).

In mixed agglutination tests mediated by RF applied to the tissue section, i.e. indirect mixed agglutination, the previously described procedure was followed (Milde and Tönder, 1968).

\section{Experiments and results}

\section{RF-ACTIVITY IN TISSUE}

Sections of frozen synovial tissue from ten RApatients were tested in mixed agglutination with:

(1) Sheep erythrocytes sensitized by various amounts of rabbit antiserum,

(2) Human erythrocytes sensitized by various amounts of anti-CD serum.

The relationship between the strength of the reaction with the tissue sections and the degree of sensitization of the erythrocytes is evident from Table I.

With sensitized sheep erythrocytes, synovial tissue from six patients (Nos 7, 10, 24, 41, 55, 56) exhibited strong activity, and tissue from the remaining four patients medium activity.

Table I Mixed agglutination. Sections of rheumatoid tissue tested with sheep erythrocytes sensitized with various amounts of rabbit antiserum and human erythrocytes sensitized by various amounts of anti-CD serum (Ripley)

\begin{tabular}{|c|c|c|c|c|c|c|c|c|c|c|}
\hline \multirow{2}{*}{$\begin{array}{l}\text { Tissue from } \\
\text { patient no. }\end{array}$} & \multicolumn{5}{|c|}{$\begin{array}{l}\text { Sensitized sheep erythrocytes } \\
\text { Number of agglutinating units of antiserum }\end{array}$} & \multicolumn{5}{|c|}{$\begin{array}{l}\text { Sensitized human erythrocytes } \\
\text { Anti-CD serum diluted }\end{array}$} \\
\hline & 4 & 2 & 1 & $1 / 2$ & $1 / 4$ & $1: 8$ & $1: 16$ & $1: 32$ & $1: 64$ & $1: 128$ \\
\hline $\begin{array}{r}7 \\
10 \\
18 \\
19 \\
24 \\
35 \\
41 \\
55 \\
56 \\
57\end{array}$ & $\begin{array}{l}3+ \\
3+ \\
3+ \\
3+ \\
3+ \\
3+ \\
3+ \\
3+ \\
2+ \\
2+\end{array}$ & $\begin{array}{l}3+ \\
3+ \\
2+ \\
3+ \\
3+ \\
3+ \\
2+ \\
3+ \\
2+ \\
1+\end{array}$ & $\begin{array}{l}1+ \\
3+ \\
1+ \\
2+ \\
2+ \\
1+ \\
2+ \\
2+ \\
2+ \\
1+\end{array}$ & $\begin{array}{l}1+ \\
2+ \\
- \\
1+ \\
1+ \\
1+ \\
1+ \\
1+\end{array}$ & $\begin{array}{l}\overline{-} \\
\overline{-} \\
\overline{1+} \\
\overline{1+} \\
\overline{-} \\
\overline{-}\end{array}$ & $\begin{array}{l}3+ \\
2+ \\
2+ \\
1+ \\
2+ \\
3+ \\
3+ \\
1+ \\
3+ \\
3+\end{array}$ & $\begin{array}{l}3+ \\
2+ \\
2+ \\
1+ \\
1+ \\
2+ \\
2+ \\
2+ \\
3+\end{array}$ & $\begin{array}{l}2+ \\
1+ \\
2+ \\
1+ \\
1+ \\
2+ \\
2 \pm \\
1+ \\
1+ \\
2+\end{array}$ & $\begin{array}{l}1 \bar{x} \\
1+ \\
\overline{1+} \\
1+ \\
1 \pm \\
\overline{-} \\
\overline{1+}\end{array}$ & $\begin{array}{l}\bar{z} \\
\overline{-} \\
\overline{1} \\
\overline{-} \\
\overline{-} \\
-\end{array}$ \\
\hline
\end{tabular}


With sensitized human erythrocytes the tissue activity was graded in a similar way. When positive reactions were obtained with the erythrocytes sensitized by anti-CD serum diluted $1: 64$ or $1: 128$, the tissue was considered strongly reactive (Nos 10, $18,24,35,41,57)$. When positive reactions were obtained only with erythrocytes sensitized by antiserum diluted $1: 8$ or $1: 16$, the tissue was considered weakly reactive (Nos 19 and 55). The tissue was considered moderately reactive if reactions were obtained with the anti-CD serum diluted $1: 32$ (Nos 7 and 56). With serum and tissue from six patients there was a fairly good correlation between the serum-RF titres in the Waaler-Rose test and the anti-CD test and the corresponding RF-activities bound in the tissues (Tables I and II). However, with patient No. 7 there was discrepancy between tissue and serum-RF judged from both test systems. With patients Nos. 41 and 57 there was strong RF-activity in the tissue with sensitized human erythrocytes, but only weak activity in serum $(1: 32)$, and with patient No. 55 the serum titre of RF reactive with human $\gamma$-globulin was high, with only weak activity in the tissue. These results indicate the existence of three different relations between the RF-activity in the tissue and the same activity in serum:

(1) Strong RF-activity in tissue and high RF-titre in serum;

(2) Strong RF-activity in tissue and low RF-titre in serum;

(3) Weak RF-activity in tissue and high RF-titre in serum.

Sections of synovial tissue from ten patients with osteoarthritis gave no reaction with sensitized human or sheep erythrocytes.

REACTION OF RF WITH RHEUMATOID TISSUE In indirect mixed agglutination, the reaction between tissue sections and weakly sensitized erythrocytes is mediated by RF added to the tissue sections before incubation with the sensitized erythrocytes (Table II). Using this weak sensitization, the erythrocytes do not attach to the tissue section in saline controls. The activity of the tissue in reaction with applied RF can be graded indirectly as previously demonstrated (Milde and Tönder, 1968). This activity varies from patient to patient, and is taken as an expression of different amounts of reactant for RF bound in the tissue. The same RA-serum was applied to tissue sections from each of the ten RA-patients. In these experiments only the sensitized sheep erythrocytes were used as indicator system. Tissue from patients Nos $7,10,19,55$, and 56 gave reaction with RAserum up to a dilution $1: 64$, whereas tissue from patients Nos. 35 and 41 gave no reaction even with undiluted RA-serum. When RA-serum was replaced by blood donor serum or RA-serum absorbed with sheep erythrocytes stromata sensitized by rabbit antiserum, no reaction was obtained.

From the data in Table II it can be concluded that there is no definite relationship between the RF-titre in serum and the amount of free reactant in the tissue. Controls with sections of synovial tissue from ten patients with osteoarthritis gave no reaction, i.e. no binding of RF. With tissue sections from two patients with chronic infectious arthritis, however, a positive reaction was obtained with the applied RA-serum in dilution $1: 4$.

\section{ABSOR PTION OF RF BY RHEUMATOID TISSUE}

Based on the findings indicating that synovial tissue from some patients contains reactant for RF in excess, free to react with added RF, four different RA-sera were titrated against sensitized human and sheep erythrocytes before and after absorption with lyophilized tissue. A decrease in RF-titre by a factor of 8 or more was considered significant absorption. A four-fold decrease was taken as doubtful absorption. With tissue from patient No. 41 , no absorption of RF reactive with rabbit $\gamma$-globulin was obtained,

Table II Indirect mixed agglutination mediated by RF between rheumatoid tissue and sheep erythrocytes sensitized by rabbit antiserum. Comparison with titre of $R F$ in patient serum

\begin{tabular}{|c|c|c|c|}
\hline \multirow{2}{*}{$\begin{array}{l}\text { Tissue from } \\
\text { patient no. }\end{array}$} & \multirow{2}{*}{$\begin{array}{l}\text { Dilution of } \\
\text { rheumatoid serum applied to } \\
\text { tissue }\end{array}$} & \multicolumn{2}{|c|}{ Titre of patient serum in } \\
\hline & & Waaler-Rose test & Anti-CD test \\
\hline $\begin{array}{r}7 \\
10 \\
18 \\
19 \\
24 \\
55 \\
56 \\
57\end{array}$ & $\begin{array}{r:r}1 & : 64 \\
1 & : 64 \\
1 & : 16 \\
1 & \vdots 64 \\
1 & : 16 \\
1 & \vdots 64 \\
1 & \vdots 64 \\
1 & :\end{array}$ & 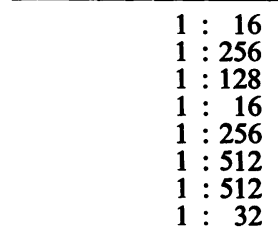 & 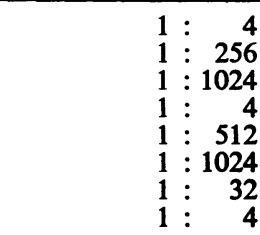 \\
\hline
\end{tabular}

For each individual tissue the sheep erythrocytes were sensitized by half of the amount of antiserum which gave the last positive reaction in the direct mixed agglutination test. See text. 
and tissue from patient No. 35 gave doubtful absorption. With tissue from the other patients, significant absorption of RF reactive with rabbit $\gamma$ globulin was obtained. Tissue from all the patients gave significant absorption of RF reactive with human $\gamma$-globulin (Table III). When the effects of absorbing autologous serum-RF and RF from other patients were compared using tissue from three different patients (Nos 18, 24, 55), it was found that tissue from two of them gave no absorption of autologous serum-RF reactive with rabbit $\gamma$-globulin, while they significantly absorbed RF from other individuals. The results corresponded well with those obtained with indirect mixed agglutination with tissue sections.

Absorption of RA-serum with synovial tissue from ten patients with osteoarthritis were studied. With tissue from six patients, no absorption of RF reactive with rabbit $\gamma$-globulin was obtained. Tissue from the other four patients gave doubtful absorption of the same RF.

With tissue from five control patients, no absorption of RF reactive with human $\gamma$-globulin was obtained. Tissue from three of them gave doubtful absorption and tissue from the remaining two patients gave significant absorption.
Tissue from the two latter control patients was tested with indirect mixed agglutination with sensitized human erythrocytes. No binding of applied RF could be shown. This discrepancy probably only reflects difference in sensitivity between the two techniques.

Lung tissue from a patient in the second control group significantly absorbed RF reactive with human $\gamma$-globulin, but only doubtful absorption of RF reactive with rabbit $\gamma$-globulin was obtained. The other control tissues gave no absorption.

The possibility of aggregation of $\gamma \mathrm{G}$ globulin in the lyophilized tissue during tissue processing and storage was considered. Aggregated $\gamma \mathbf{G}$ globulin might then absorb RF from serum. Absorption of serum with freshly disintegrated, non-lyophilized, tissue preparations served as a control for this (Table IV). In this experiment significant absorption of RF reactive with rabbit $\gamma$-globulin was obtained with RA-synovial tissue. Normal synovial tissue gave only doubtful absorption of RF. Only two absorptions with RA-tissue were necessary for the complete exhaustion of RF-activity in serum (512 $<16$ ). Three absorptions were necessary for the doubtful absorption of RF with normal synovial tissue.

Table III Titre of $R F$ in four sera tested against sensitized sheep erythrocytes (SSC) and sensitized human erythrocytes (SHC) before and after absorption with synovial tissue from RA-patients

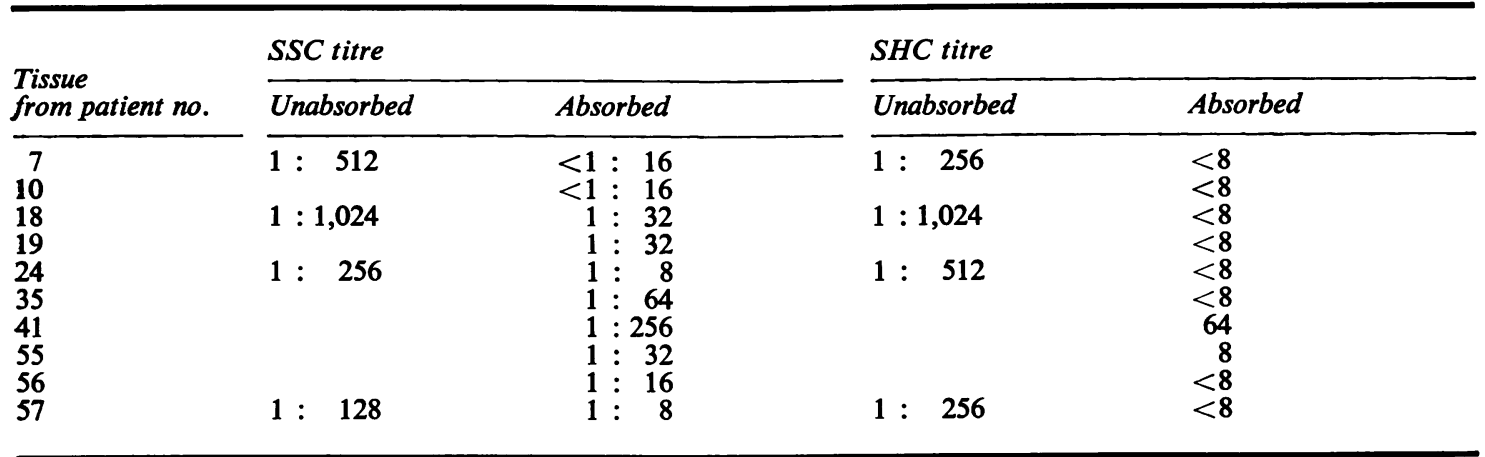

Table IV Titre of RF in serum tested against sensitized sheep erythrocytes (SSC) and sensitized human erythrocytes $(\mathrm{SHC})$ before and after absorption with freshly disintegrated tissue

\begin{tabular}{|c|c|c|c|c|}
\hline \multirow[b]{2}{*}{ Tissue } & \multicolumn{2}{|l|}{ SSC titre } & \multicolumn{2}{|l|}{ SHC titre } \\
\hline & Unabsorbed & Absorbed & Unabsorbed & Absorbed \\
\hline $\begin{array}{l}\text { RA-synovial tissue } \\
\text { Normal synovial tissue } \\
\text { Liver } \\
\text { Spleen } \\
\text { Nerve } \\
\text { Cancer } \\
\text { Infected lung }\end{array}$ & $\begin{array}{l:l}1 & : 512 \\
1 & : 512 \\
1 & : 512 \\
1 & : 512 \\
1 & : 512 \\
1 & : 512 \\
1 & : 512\end{array}$ & $\begin{array}{rl}<1 & : 16 \\
1 & : 128 \\
1 & 512 \\
1 & : 128 \\
1 & : 256 \\
1 & : 128 \\
1 & : 128\end{array}$ & 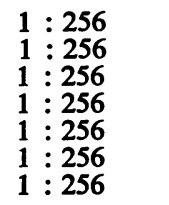 & $\begin{array}{l:r}1 & : 16 \\
1 & 16 \\
1 & 128 \\
1 & : 256 \\
1 & 128 \\
1 & 128 \\
1 & : 32\end{array}$ \\
\hline
\end{tabular}


In the human test system only one absorption with RA-tissue was necessary to empty the serum completely of RF, whereas three absorptions with normal synovial tissue were necessary to cause a titre fall from $1: 256$ to $1: 16$.

The difference between rheumatoid and normal synovial tissue in their capacity to absorb RF from sera, therefore seems to be of a quantitative nature.

The results of the absorption experiments give additional evidence for the presence of bound RFreactant in RA-tissue. Some absorption was also obtained with non-rheumatoid synovia and tissue with chronic inflammation, indicating that some RFreactant may also localize in such tissue.

EFFECT OF INCUBATION OF TISSUE AT $56^{\circ} \mathrm{C}$.

As earlier described, heating the tissue sections at $56^{\circ} \mathrm{C}$. in saline abolished the direct mixed agglutination reaction (Milde and Tönder, 1968). The tissue activity in indirect mixed agglutination was also considerably reduced, indicating that the RFreactant is also eluted from the sections by this procedure.

After treatment of tissue sections in $\mathbf{1 5}$ per cent. $\mathrm{NaCl}$ at room temperature, some impairment of the direct mixed agglutination was observed. With most tissue sections a strongly positive reaction $(3+)$ was reduced to $2+$ or $1+$. The binding of applied RF was likewise reduced, but not completely abolished.

Acting on these results, washed lyophilized tissue from patients Nos 18 and 24 were submitted to the same procedures. The tissues were used in absorption experiments with one RA-serum. Before treatment, tissue from both patients absorbed significantly RF reactive with both human and rabbit $\gamma$ globulin. After treatment with 15 per cent. $\mathrm{NaCl}$ at room temperature, only doubtful absorption of RF reactive with rabbit $\gamma$-globulin was obtained with tissue sediments from both patients, while both sediments still significantly absorbed $\mathrm{RF}$ reactive with human $\gamma$-globulin. After treatment at $56^{\circ} \mathrm{C}$. no absorption of RF reactive with rabbit $\gamma$-globulin was obtained with tissue sediment from the two patients, while both sediments still significantly absorbed RF reactive with human $\gamma$-globulin.

These experiments indicate that the reactant for RF reactive with rabbit $\gamma$-globulin is destroyed or eluted from the tissue by this treatment. The reactant for $\mathbf{R F}$ reactive with human $\gamma$-globulin is seemingly not influenced.

EFFECT OF INCUBATION OF TISSUE AT LOW PH Five different RA-sera were examined by the WaalerRose rest and anti-CD test before and after absorption with tissue from patients Nos 18 and 19 treated with acid buffer. The untreated tissues from both patients significantly absorbed RF from all five sera.
Treated tissue from patient No. 18 showed no absorption of RF reactive with rabbit $\gamma$-globulin from four of the sera, while there was significant absorption from one serum. Treated tissue from patient No. 19 absorbed RF reactive with rabbit $\gamma$-globulin significantly from three of the sera, while doubtful absorption was obtained with one serum, and none with the remaining serum. Treated tissue from both patients significantly absorbed RF reactive with human $\gamma$-globulin from all five sera. The experiments indicate that the reactant for RF reactive with human $\gamma$-globulin is not influenced by treatment of tissue at low pH; the reactant for RF reactive with rabbit $\gamma$-globulin in some sera may be eluted from the tissue by such treatment.

\section{'RECOMBINATION' OF TISSUE SEDIMENT \\ AND HEAT-ELUATE}

Washed sediment of tissue from patient No. 24 after elution with 15 per cent. $\mathrm{NaCl}$ at $56^{\circ} \mathrm{C}$. was suspended in the eluate from the same tissue at room temperature. After incubation for $90 \mathrm{~min}$. at room temperature, the suspension was centrifuged and the sediment washed. With this sediment, significant absorption of RF reactive with rabbit $\gamma$-globulin was again observed.

This experiment shows that the eluate contains reactant which can combine with the tissue, again imposing reactivity upon the inactive sediment.

\section{Discussion}

By mixed agglutination, binding of sensitized human and sheep erythrocytes could be demonstrated with synovial tissue from all the ten RA-patients in this study. From inhibition experiments with denatured $\gamma$-globulin and antibodies to $\gamma \mathbf{M}$ (Milde and Tönder, 1968), it was concluded that the reastion depended on RF bound in the tissues. The strength of the reaction with sensitized human and sheep erythrocytes, indicating the amount of RF bound in the tissue, varied from patient to patient. There was a fairly good correlation between the strength of the reaction in the two systems. However, with one patient (No. 55), the tissue reacted strongly with sensitized sheep erythrocytes, but only weakly with sensitized human erythrocytes.

Tissue from as many as eight of the patients also reacted with applied RF by indirect mixed agglutination. As earlier defined (Milde and Tönder, 1968), the strength of this reaction indicates the amount of $\gamma$-globulin reactant in tissue free to react with applied RF. Considering the amount of RF and reactant bound in tissue from an individual joint, and comparing these with the RF-titre in serum from the corresponding patient, two types of reaction patterns are revealed (Table V, opposite): 
Table V Reactivity of synovial tissue sections in direct and indirect mixed agglutination. Comparison with titre of $R F$ in corresponding sera

\begin{tabular}{|c|c|c|c|}
\hline \multirow{2}{*}{$\begin{array}{l}\text { Tissue from } \\
\text { patient no. }\end{array}$} & \multicolumn{2}{|l|}{ Reactivity of tissue } & \multirow{2}{*}{$\begin{array}{l}\text { Titre of } R F \\
\text { in serum }\end{array}$} \\
\hline & in direct mixed agglut ination & in indirect mixed agglutination & \\
\hline $\begin{array}{r}7 \\
35 \\
41\end{array}$ & $\begin{array}{l}\text { Strongly reactive } \\
\text { Medium reactive } \\
\text { Strongly reactive }\end{array}$ & $\begin{array}{l}\text { Strongly reactive } \\
\text { None } \\
\text { None }\end{array}$ & $\begin{aligned}<1 & : 16 \\
1 & : 512 \\
1 & : 256\end{aligned}$ \\
\hline
\end{tabular}

Sections of rheumatoid tissue tested with sheep erythrocytes sensitized with various amounts of rabbit antiserum.

(1) Ample amounts of both RF and free reactant in tissue and no RF in serum (No. 7);

(2) Ample amounts of RF in tissue, but no free reactant, and with RF in serum (Nos 35 and 41).

However, judged from the absorption experiments, tissue from other patients (e.g. No. 24) had free reactant in spite of high RF-titre in serum, a situation in which one would perhaps expect all reactant to be saturated with RF. The reason for this is uncertain. Possibly a high RF-titre in serum does not necessarily reflect bound RF in excess in an individual joint. It should be stressed, however, that isologous RF-sera were used in these tissue absorption experiments, and not autologous sera. When the effects of absorbing autologous serum-RF and RF from other patients were compared, it was found that tissue from some patients gave no absorption of autologous serum-RF reactive with rabbit $\gamma$-globulin, while they significantly absorbed RF in sera from other individuals.

This possibly signifies the existence of several reactants of individual specificity in the tissue.

Synovial tissue from all the RA-patients and from two of the patients with osteoarthritis significantly absorbed RF reactive with human $\gamma$-globulin from sera. Significant absorption of such RF was also obtained with freshly disintegrated normal synovia.

This probably reflects the greater reactivity of the reaction between RF reactive with human $\gamma$-globulin and reactant $\gamma$-globulin in the tissue. Absorption of RF reactive with rabbit $\gamma$-globulin seems, on the other hand, to be more specific for RA as disease as none of the control tissues absorbed significantly such RF. Pertinent to these results are those obtained by Milgrom and Tönder (1965) with absorption of RF to human immune-complexes. Heterospecific RF-activity was left in RA-sera after complete absorption of isospecific RF.

In this study, heating the tissue sections at $56^{\circ} \mathrm{C}$. abolished the ability of synovial tissue to react with sensitized erythrocytes, i.e. RF was eluted from the tissue. The binding of applied RF was likewise markedly reduced, i.e. the reactant for RF was also eluted. Heated synovial tissue also gave much weaker absorption of RF reactive with rabbit $\gamma$-globulin than unheated tissue. Furthermore, the absorbing effect of heat-treated tissue was restored after mixing with heat-eluate at room temperature. This observation suggested the possibility of recombining at a lower temperature of antigen-antibody complexes dissociated at $56^{\circ} \mathrm{C}$. in 15 per cent. $\mathrm{NaCl}$. Such recombined complexes may then again become reactive with RF. These observations seem to support the idea that antigen-antibody complexes in tissue function as reactants for RF reactive with rabbit $\gamma$-globulin in vitro.

However, neither treatment with high salt solution at $56^{\circ} \mathrm{C}$., nor with acid buffer, seemed to influence the ability of the tissue to absorb RF reactive with human $\gamma$-globulin. This indicates that the reactant for such RF may be of another nature, possibly $\gamma$-globulins aggregated physico-chemically. Several authors have shown that RF can be absorbed with sensitized erythrocytes (Heller, Jacobson, Kolodny, and Kammerer, 1954) and with other antigen-antibody complexes (Vaughan, 1956; Edelman, Kunkel, and Franklin, 1958; Aho and Simons, 1963). These observations, together with the data obtained in this study about the reactant for RF in tissue, point indirectly to the presence of antigen-antibody complexes in the tissue as reactant for RF reactive with rabbit $\gamma$-globulin. Possibly the molecular structure of the antibody part of such complexes is changed during the binding with antigen, thus providing the antibody with a 'new' specificity against which RF is directed (Najjar and Fisher, 1955; Najjar and Fisher, 1956). It is also conceivable that structural alteration of $\gamma$-globulins reactive with RF may be caused by several nonimmunological physico-chemical processes taking place in the tissue during inflammation. Altered $\gamma$ globulin reactive with serum-RF in synovial effusions from certain RA-patients was demonstrated by Hannestad (1967). The question whether altered $\gamma$ globulins reactive with RF in vivo are antigenantibody complexes or $\gamma$-globulins aggregated physico-chemically, remains to be answered. However, the data obtained in this study give some indications for the existence of both antigen-antibody 
complexes and aggregated $\gamma$-globulins as reactants for RF.

Attempts at serological characterization of tissue eluates are at present in progress. Preliminary results show that both RF and $\gamma$-globulins reactive with RF in inhibition experiments in vitro may be eluted from rheumatoid synovia.

\section{Summary}

The amounts of RF and reactant for RF bound in synovial tissue from patients with rheumatoid arthritis were assessed by application of the mixed agglutination procedure with tissue sections using erythrocytes sensitized with corresponding antibodies of human and rabbit origin.
Additional evidence for the presence of bound RF-reactant in RA-tissue was found by absorbing RF from sera with lyophilized RA-synovial tissue. No definite relationship between RF-activity in tissue and the same activity in serum was found, neither between the amount of free RF-reactant in tissue and RF-titre in serum.

Absorption of RF reactive with rabbit $\gamma$-globulin seemed to be more specific for RA-tissue than absorption of RF reactive with human $\gamma$-globulin. Absorption of variously treated synovial tissue gave results indicating that the reactant in tissue for $\mathbf{R F}$ reactive with rabbit $\gamma$-globulin is possibly of another nature than the reactant for RF reactive with human $\gamma$-globulin.

\section{References}

Aнo, K., AND Simons, K. (1963) Arthr. and Rheum., 6, 676 (Studies of the antibody nature of the rheumatoid factor. Reaction of the rheumatoid factor with human specific precipitates and with native human $\gamma$-globulin).

EDEBO, L. (1960) J. biochem. microbiol. Technol. Engng, 2, 453 (A new press for the disruption of micro-organisms and other cells).

Edelman, G. M., Kunkel, H. G., ANd Franklin, E. C. (1958) J. exp. Med., 108, 105 (Interaction of the rheumatoid factor with antigen-antibody complexes and aggregated $\gamma$-globulin).

HANNESTAD, K. (1967) Clin. exp. Immunol., 2, 511 (Presence of aggregated $\gamma$ globulin in certain rheumatoid synovial effusions).

Heller, G., JACobson, A. S., Kolodny, M. H., AND Kammerer, W. H. (1954) J. Immunol., 72, 66 (The hemagglutination test for rheumatoid arthritis. II. The influence of human plasma fraction II ( $\gamma$-globulin) on the reaction).

MILDE, E.-J., AND TöNDER, O. (1968) Arthr. and Rheum., 11, 573 (Demonstration of rheumatoid factor in tissue by mixed agglutination with tissue sections).

Milgrom, F., AND TöNDER, O. (1965) Ibid., 8, 203 (Multiplicity of rheumatoid factor).

NAJJAR, V. A., AND FISHER, J. (1955) Science, 122, 1272 (Mechanism of antibody-antigen reaction).

(1956) Biochem. biophys. Acta (Amst.), 20, 158 (The mechanism of antibody-antigen reaction).

VAUGHaN, J. H. (1956) J. Immunol., 77, 181 (Behavior of the rheumatoid arthritis agglutinating factor with immune precipitates). 